\title{
Electrochemical and Metallographic Evaluation of Alloys C-22 and 625
}

\author{
A.K. Roy \\ D.L. Fleming \\ B.Y. Lum
}

May 1997

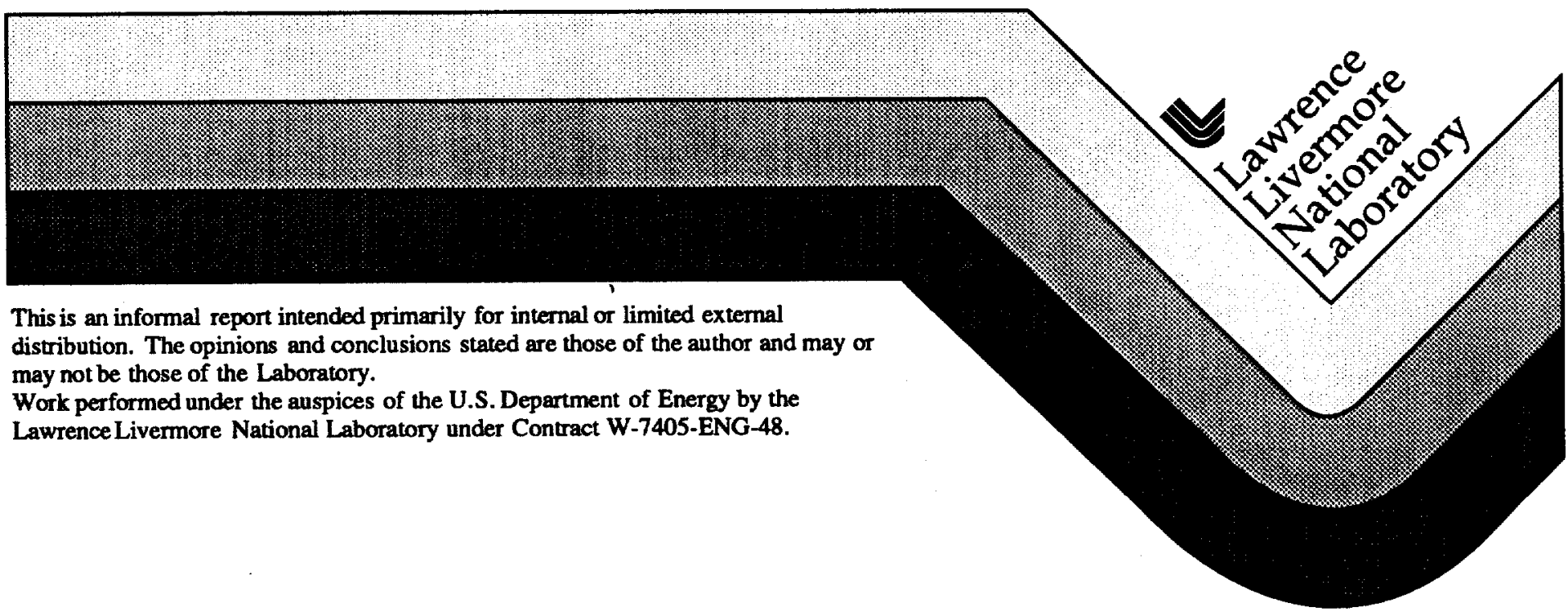




\section{DISCLAIMER}

This document was prepared as an account of work sponsored by an agency of the United States Government. Neither the United States Government nor the University of California nor any of their employees, makes any warranty, express or implied, or assumes any legal liability or responsibility for the accuracy, completeness, or usefulness of any information, apparatus, product, or process disclosed, or represents that its use would not infringe privately owned rights. Reference herein to any specific commercial product, process, or service by trade name, trademark, manufacturer, or otherwise, does not necessarily constitute or imply its endorsement, recommendation, or favoring by the United States Government or the University of California. The views and opinions of authors expressed herein do not necessarily state or reflect those of the United States Government or the University of California, and shall not be used for advertising or product endorsement purposes.

This report has been reproduced directly from the best available copy.

Available to DOE and DOE contractors from the Office of Scientific and Technical Information

P.O. Box 62, Oak Ridge, TN 37831

Prices available from (615) 576-8401, FTS 626-8401

Available to the public from the

National Technical Information Service

U.S. Department of Commerce

5285 Port Royal Rd.,

Springfield, VA 22161 
Electrochemical and Metallographic Evaluation of Alloys C-22 and 625

\author{
Ajit K. Roy \\ Dennis L. Fleming \\ Beverly Y. Lum
}

May 1997 
Electrochemical and Metallographic Evaluation of Alloys C-22 and 625
Ajit K. Roy

Framatome Cogema Fuels

c/o LLNL (On Assignment)

P.O.Box 808, M/S: L-369

Livermore, CA 94551
Dennis L. Fleming

Beverly Y. Lum

Lawrence Livermore

National Laboratory

P.O.Box 808

Livermore, CA 94551
Abstract

Electrochemical cyclic potentiodynamic polarization (CPP) experiments were performed on Alloys C-22 and 625 to evaluate their susceptibility to localized corrosion in acidic brines of various salt content at $90^{\circ} \mathrm{C}$. The microstructures of both tested and untested specimens were evaluated by optical microscopy. This paper presents the results showing the effect of chloride ion (Cl) concentration on the pitting and crevice corrosion behavior of these alloys, and the relationship of the observed microstructures to the resulting surface degradation modes.

\section{Background}

The results (") of a recent electrochemical corrosion study performed on several candidate inner container waste package materials at the Lawrence Livermore National Laboratory (LLNL) have shown that nickel-chromiummolybdenum (Ni-Cr-Mo) Alloy C-22 was immune to localized attack in brines of various $\mathrm{pHs}$ at temperatures up to $90^{\circ} \mathrm{C}$. More recently, Alloy 625 , also a Ni-Cr-Mo alloy, was included in the electrochemical corrosion testing program to compare its localized corrosion resistance to that of Alloy C-22. This paper presents the results of CPP tests involving both these alloys in comparable environments. Furthermore, the results of metallographic evaluation of both tested and untested specimens are presented.

\section{Materials and Environments}

Materials tested include Ni-Cr-Mo Alloys C-22 and 625. Their chemical compositions are given in Table 1. Test specimens were fabricated from annealed materials by an outside vendor. Additional thermal treatments were not given to these specimens prior to their exposure to the test environments.

Tests were conducted in deaerated acidic brines containing 1 to 10 weight percent (wt\%) $\mathrm{NaCl}$ at $90^{\circ} \mathrm{C}$. Acidification was done by adding sulfuric acid to the brine. The $\mathrm{pH}$ of these solutions ranged between 2 and 3 .

\section{Experimental Procedure}

A three-electrode technique was used to perform CPP experiments in a Pyrex cell using a cylindrical test specimen as the working electrode, two graphite counter electrodes, and a Luggin capillary connected to a $\mathrm{Ag} / \mathrm{AgCl}$ reference electrode. The test specimens were polished with 600-grit paper and cleaned with distilled water, acetone and ethanol prior to their exposure to the test environments.

Electrochemical potential was applied to the test specimens at a scan rate of $0.17 \mathrm{mV} / \mathrm{sec}$ using an EG\&G Model 273 or 283 potentiostat, controlled by an IBMcompatible PC with EG\&G corrosion software. Forward potential scans were done in the noble direction commencing at the stable corrosion potential $\left(\mathrm{E}_{\mathrm{corr}}\right)$, and continuing to a potential sufficiently noble to either cause pitting or indicate pit-like behavior prior to reversing the potential scan at the same rate.

For alloys susceptible to pitting corrosion, a clockwise hysteresis loop is traced during reverse scan. Two pitting parameters, namely the critical pitting potential $\left(E_{\text {pit }}\right)$, and the repassivation or protection potential $\left(\mathrm{E}_{\text {proa }}\right)$ can be determined from these tests. The value of $E_{\text {pit }}$ denotes the potential at which current increases abruptly on the forward scan, indicating the possibility of pit initiation. $E_{\text {prot }}$ indicates the potential at which current returns to passive values during the reverse scan, indicating repassivation of pits.

The $\mathrm{pH}$ of the test solution was measured at room temperature prior to initiation of each experiment. At the conclusion of each test, the specimen was cleaned with distilled water, acetone and ethanol. The cleaned specimen was visually examined, followed by an optical microscopic evaluation to detect the presence or absence of pitting. Furthermore, metallographic evaluation of both tested and untested specimens was performed using conventional techniques to characterize and compare the metallurgical microstructures of both alloys. The specimens were electrolytically etched in $4 \%$ nital (a mixture of nitric acid and ethanol) prior to their evaluation. 


\section{Results and Discussion}

\section{Electrochemical Study}

Results indicate that Alloy C-22 was immune to pitting corrosion in all salt solutions tested. Furthermore, this alloy showed very little or no crevice corrosion tendency. In general, the specimen surface was unattacked.

Contrary to this observation, Alloy 625 exhibited a tendency to surface degradation including crevice corrosion, pitting corrosion, and cracking. A comparison of specimen surface appearance of both alloys tested in acidified brine containing $10 \mathrm{wt} \% \mathrm{NaCl}$ is illustrated in Figure 1.

The initiation of pitting in susceptible alloys is the result of localized breakdown of their passive films due to the presence of aggressive anions such as $\mathrm{Cl}^{-}$. Two theories have been proposed ${ }^{(2.3)}$ to explain the concept of $E_{p i n}$, at or above which passive metals and alloys may undergo pitting in the presence of halide ions. One of these theories, proposed by Hoar et al $^{(2)}$, suggests that pitting corrosion occurs as a result of adsorption of aggressive anions such as $\mathrm{Cl}^{-}$on an oxide film, followed by penetration of this film under the influence of an electrostatic field. Pits initiate when the field across the film-solution interface reaches a critical value.

An alternate model, proposed by Leckie and Uhlig ${ }^{(3)}$, is based on reversible competitive adsorption of $\mathrm{Cl}^{-}$into the oxide/liquid interface (double layer) with oxygen for sites on the alloy surface. Oxygen normally has higher affinity than $\mathrm{Cl}^{-}$for an adsorption site, but as the electrochemical potential of the alloy is driven in the noble direction, more $\mathrm{Cl}^{-}$ions move into the double layer. At a sufficiently high concentration corresponding to $E_{\text {pito }}$ $\mathrm{Cl}^{-}$ions succeed at favored sites in destroying passivity by displacing adsorbed oxygen ions.

The relationship between $\mathrm{E}_{\mathrm{pit}}$ and $\mathrm{Cl}^{-}$concentration for Alloys C-22 and 625 in acidic brines is illustrated in Figure 2. It appears that for Alloy 625, $E_{\text {pit }}$ was gradually shifted to more active values with increasing $\mathrm{Cl}^{-}$concentration. A similar effect of $\mathrm{Cl}^{-}$concentration on $E_{\text {pit }}$ has been reported elsewhere ${ }^{(4-7)}$ for alloys susceptible to pitting corrosion. For Alloy C-22, even though $\mathrm{E}_{\text {pit }}$ was shifted to a more active value due to an increase in $\mathrm{NaCl}$ concentration from 1 to $5 \mathrm{wt} \%$, above 5 to $7 \mathrm{wt} \% \mathrm{NaCl} \mathrm{E}_{\mathrm{pit}}$ was shifted to more noble values.

Except in $1 \mathrm{wt} \% \mathrm{NaCl}$ solution, a clockwise hysteresis loop was traced for Alloy 625 during reverse potential scan in all environments tested, identifying $E_{\text {pit }}$. But $E_{\text {prot }}$ could not be determined from these CPP diagrams since the return polarization curve did not intersect the forward polarization curve at the passive current density (Figure 3), thus, showing no repassivation phenomenon in these tests.

For Alloy C-22, which did not exhibit any pitting susceptibility, the return polarization curve followed a counter-clockwise path upon reversal of the potential scan. The critical potential became sufficiently noble to overlap the transpassive region, as shown in Figure 4. It has been suggested ${ }^{(8,9)}$ that when the electrochemical potential of a passivated alloy is raised sufficiently, the potential drop across the double layer may often become high enough for the oxidation of entities in the solution often that of water, but especially in concentrated solutions. This may result in the formation of oxides on the alloy surface as anodic products, and uniform corrosion of the alloy may then occur with little or no localized attack. Such a phenomenon may possibly account for the absence of pitting in Alloy C-22.

\section{Metallographic Evaluation}

The results of metallographic evaluation are illustrated in Figures 5 through 8. Figures 5 and 6 show the microstructures of untested and polarized Alloy 625 specimens, respectively. An examination of these microstructures reveals precipitation in one direction, possibly the direction of working. Furthermore, the polarized specimen shows grain boundary attack upon exposure to the test solution.

It is well known that most high nickel chromium bearing alloys can be made susceptible to intergranular corrosion in certain corrosive environments as a results of improper heat treatment following fabrication. If these austenitic alloys are heated in the temperature range of 500 to $850^{\circ} \mathrm{C}\left(932\right.$ to $\left.1562^{\circ} \mathrm{F}\right)$ or are allowed to cool slowly through this temperature range, the carbon in the vicinity of the grain boundaries will diffuse toward the boundaries and there combine with chromium to form chromium carbides. These carbides bind considerable quantities of chromium, thereby leaving the grain boundaries depleted of $\mathrm{Cr}$ and therefore susceptible to preferential attack by a corroding medium. This phenomenon is commonly known as sensitization.

One way of reducing the tendency to sensitization is to reduce the carbon content of the alloy (as in Types 304L and $316 \mathrm{~L}$ stainless steels). The other way is to stabilize the alloy with $\mathrm{Ti}$ or $\mathrm{Nb}$ (as in Types 321 and 347 stainless steels). These elements have a greater affinity for carbon than $\mathrm{Cr}$, binding the carbon as titanium or niobium carbides and suppressing the formation of 
chromium carbides. But the avoidance of sensitization effects in $\mathrm{Cr}$ bearing alloys of higher Ni content is more difficult than with the 300 series stainless steels. Carbon solubility is considerably less in the higher $\mathrm{Ni}$ alloys so that reduction in carbon content or addition of stabilizing elements such as $\mathrm{Nb}$ or $\mathrm{Ti}$ is less effective.

As mentioned earlier, all specimens were fabricated by a qualified outside vendor from annealed materials. The precise annealing temperature and time at temperature for either alloy are not available from this vendor. But their chemical composition and mechanical properties, provided by the vendor, meet the requirements of the respective ASTM Designation. No attempt has been made to analyze the precipitates observed in Figures 5 and 6. However, there are indications in the open literature $e^{(10,11)}$ that for standard solution-annealed Alloy 625 , these precipitates could be chromium and molybdenum-rich carbides of the type $\mathrm{M}_{23} \mathrm{C}_{6}$ and $\mathrm{M}_{6} \mathrm{C}$, which deplete the $\gamma$ matrix in these elements in the vicinity of the grain boundaries.

The metallurgical microstructures of untested and polarized specimens of Alloy C-22 are shown in Figures 7 and 8, respectively. Scattered precipitates are observed along grain boundaries and within grains. It has been suggested ${ }^{(10)}$ that carbides of the $\mathrm{M}_{6} \mathrm{C}$ type can be randomly distributed throughout the austenitic matrix in Alloy C-22 regardless of heat treatment and with no apparent effect on corrosion resistance. Thus, it is possible that the absence of pitting in this alloy could be due to the lack of continuous precipitation along the grain boundaries.

\section{Summary and Conclusions}

$\mathrm{Ni}-\mathrm{Cr}-\mathrm{Mo}$ Alloys C-22 and 625 were studied for evaluating their localized corrosion behavior in $90^{\circ} \mathrm{C}$ acidic brines containing 1 to $10 \mathrm{wt} \% \mathrm{NaCl}$ using $\mathrm{CPP}$ technique. The effect of $\mathrm{Cl}^{-}$concentration on $\mathrm{E}_{\text {pit }}$ was investigated. The metallurgical microstructures of untested and polarized specimens were also evaluated. The conclusions drawn from this study are the following:

- Alloy 625 became susceptible to pitting corrosion, crevice corrosion, and surface attack.

- Alloy C-22 was immune to localized attack under all environmental conditions studied, thus demonstrating its improved corrosion resistance.

- For Alloy $625, \mathrm{E}_{\mathrm{pit}}$ was gradually shifted to more active values with increasing $\mathrm{Cl}^{-}$concentration, confirming observations by other investigators. But for Alloy C-22, above $5107 \mathrm{wt} \% \mathrm{NaCl}, \mathrm{E}_{\text {pit }}$ was shifted to more noble values.

- Alloy 625 showed a conventional hysteresis loop upon reversal of the potential scan. On the contrary, a counter-clockwise path was observed with Alloy C22 during the reverse potential scan, indicating absence of localized attack possibly due to the formation of oxides on the alloy surface.

- The metallurgical microstructures of polarized Alloy 625 specimens revealed intergranular corrosion. In contrast, random precipitation was observed along grain boundaries and within grains of Alloy C-22.

\section{Acknowledgments}

This work was supported by the U.S. Department of Energy, Office of Civilian Radioactive Waste Management, Yucca Mountain Site Characterization Office, Las Vegas, NV, and performed under the auspices of the U.S. Department of Energy by the Lawrence Livermore National Laboratory under contract number W-7405-ENG-48 and by TRW Environmental Safety Systems Inc. under contract number DE-AC0 1RW00134.

Acknowledgment is also made to Robert Kershaw for his assistance in metallographic study.

\section{References}

1. A. K. Roy, D. L. Fleming and B. Y. Lum, "Effect of Environmental Variables on Localized Corrosion of High-Performance Container Materials," LLNL UCRL-JC-125329 January 1997, to be presented at the Fifth International Conference on Nuclear Engineering, Nice. France, May 26-30, 1997

2. T. P. Hoar, D. C. Mears and G. P. Rothwell, "The Relationships Between Anodic Passivity, Brightening and Pitting," Corrosion Science Vol. 5, pp 279-289 (1965)

3. H. P. Leckie and H. H. Uhlig, "Environmental Factors Affecting the Critical Potential for Pitting in 18-8 Stainless Steel," J. Electrochem. Soc. Vol. 113, No. 12, pp 1262-1267 (1966) 
4. A. U. Malik, P. C. M. Kutty, A. N. Siddiqi, I. N. Andijani and $\mathrm{S}$. Ahmed, "The Influence of $\mathrm{pH}$ and Chloride Concentration on the Corrosion Behavior of AISI 316L Steel in Aqueous Solutions," Corrosion Science Vol. 33, No. 11, pp 1809-1827 (1992)

5. J-H. Wang, C. C. Su and Z. Szklarska-Smialowska,

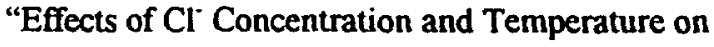
Pitting of AISI 304 Stainless Steel." Corrosion Vol. 44, No. 10, pp 732-737 (1988)

6. R. Ambat and E. S. Dwarakdasa, "Studies on the Influence of Chloride lon and $\mathrm{pH}$ on the Electrochemical Behavior of Aluminum Alloys $\mathbf{8 0 9 0}$ and 2014," J. Appl. Electrochem. Vol. 24, No. 9, pp $911-916$ (1994)

7. N. Sridhar and G. A. Cragnolino, "Applicability of Repassivation Potential for Long-Term Prediction of Localized Corrosion of Alloy 825 and Type 316L Stainless Steel," Corrosion Vol. 4, No. 11, pp 885-894 (1993)

8. J. Horvath and H. H. Uhlig, "Critical Potentials for Pitting Corrosion of $\mathrm{Ni}, \mathrm{Cr}-\mathrm{Ni}, \mathrm{Cr}-\mathrm{Fe}$, and Related Stainless Steels," J. Electrochem. Soc. Vol. 115, No. 8, pp 791-795 (1968)

9. T. P. Hoar, "The Production and Breakdown of the Passivity of Metals," Corrosion Science Vol. 7, pp 341-355 (1967)

10. M. H. Brown and R. W. Kirchner, "Sensitization of Wrought High Nickel Alloys," Corrosion Vol. 29, No. 12 (1973)

11. R. Cozar, M. Rouby, B. Mayonobe and C. Morizot, "Mechanical Properties, Corrosion Resistance and Microstructure of both Regular and Titanium Hardened 625 Alloys," Proc. Int. Symp. Metall. Appl. Superalloys 718, 625 Var. Deriv. Ed(s): E. A. Loria, Pubs: Miner. Met. Mater. Soc., Warrendale, Pa, pp 423-436 (1991) 
Table 1

Chemical Composition of Materials Tested (wt\%)

\begin{tabular}{|c|c|c|c|c|c|c|c|c|c|c|c|c|c|c|c|}
\hline Material & Heat No & $\underline{\mathrm{C}}$ & $\underline{\mathrm{Mn}}$ & $\underline{\mathbf{P}}$ & $\underline{\mathbf{S}}$ & $\underline{\mathrm{Si}}$ & $\underline{\mathrm{Ni}}$ & $\underline{\mathrm{Cr}}$ & $\underline{\text { Mo }}$ & $\underline{\mathrm{Fe}}$ & $\underline{\mathrm{Ti}}$ & $\underline{\mathrm{Al}}$ & $\underline{C_{0}}$ & $\underline{\mathbf{W}}$ & Others \\
\hline Alloy C-22 & $\mathrm{J} 244$ & 0.004 & 0.21 & 0.004 & $<0.001$ & 0.03 & Bal & 20.65 & 14.08 & 2.61 & -. & -- & 0.11 & 3.29 & $V: 0.02$ \\
\hline Alloy C-22 & L380 & 0.004 & 0.15 & 0.010 & 0.007 & 0.027 & Bal & 21.40 & 13.41 & 4.90 & -- & -- & 1.50 & 3.10 & $V: 0.12$ \\
\hline Alloy 625 & L704 & 0.020 & 0.08 & 0.006 & 0.001 & 0.08 & Bal & 21.67 & 8.90 & 3.86 & 0.27 & 0.29 & 0.10 & -- & $\mathrm{Nb}+\mathrm{Ta}: 3.45$ \\
\hline
\end{tabular}




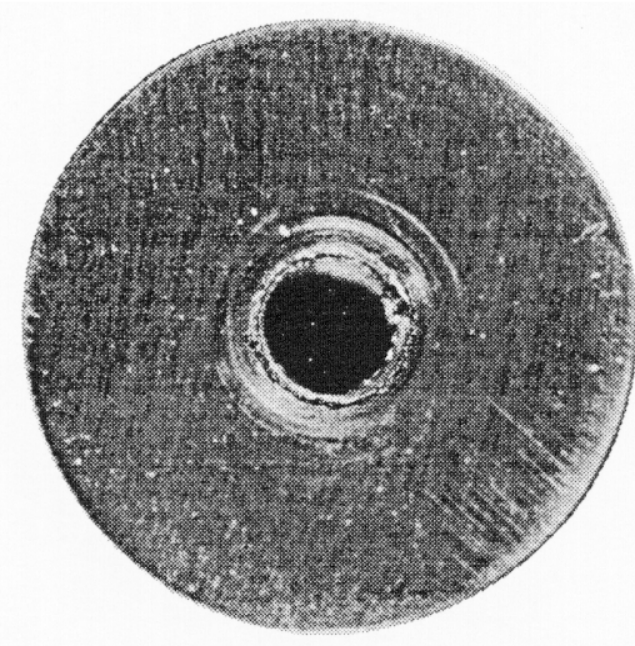

Alloy C-22

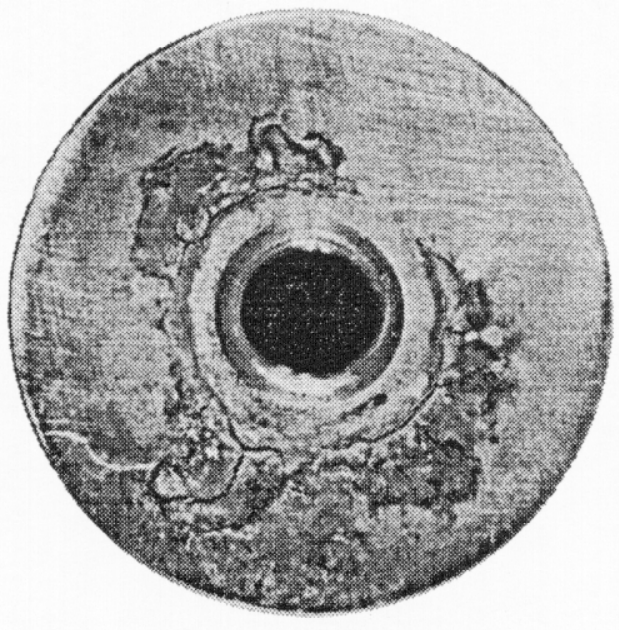

Alloy 625

Figure 1. Surface Appearance (Vertical Mode) of Alloys C-22 and 625 in Acidic Brines Containing $10 \mathrm{wt} \% \mathrm{NaCl}$ at $90^{\circ} \mathrm{C}$

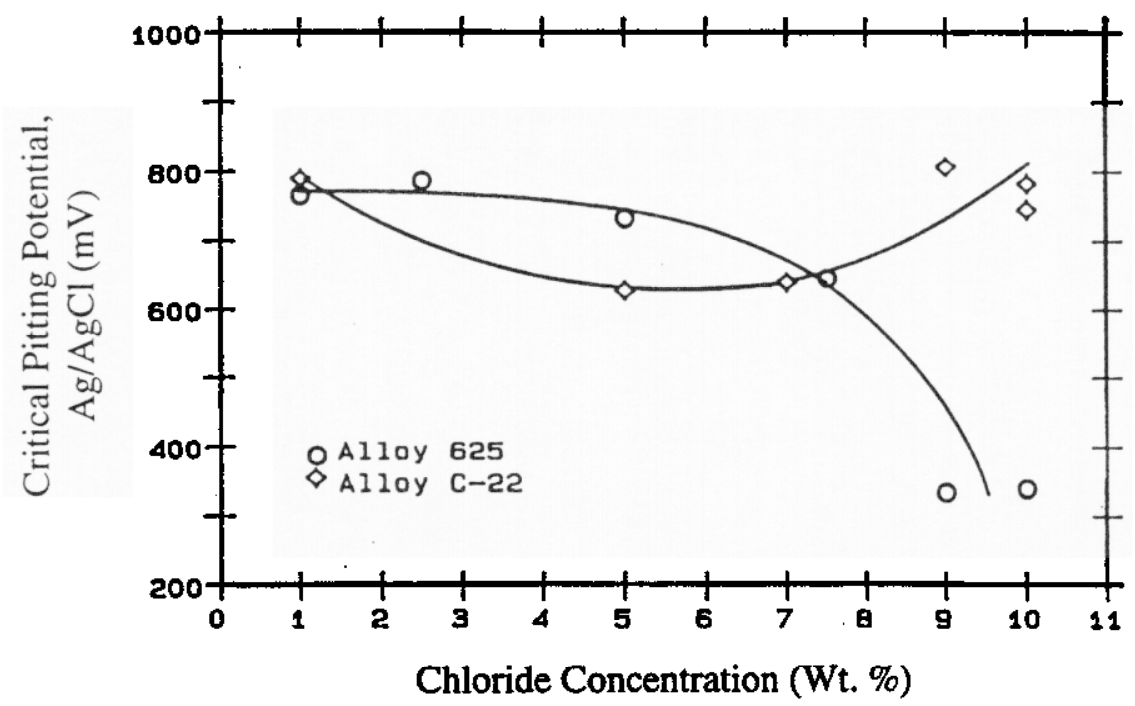

Figure 2. Critical Pitting Potential vs Chloride Concentration in Acidic Brines at $90^{\circ} \mathrm{C}$ 


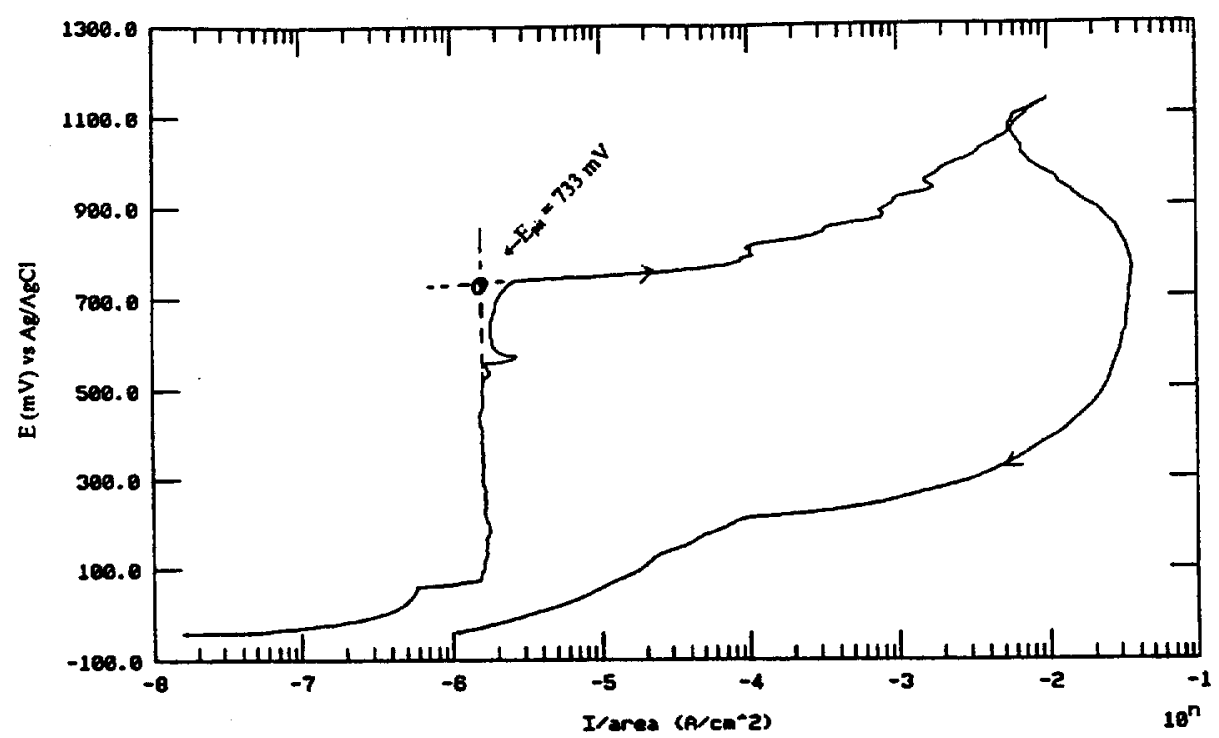

Figure 3. CPP Diagram of Alloy 625 in Acidic Brine Containing $5 \mathrm{wt} \% \mathrm{NaCl}$ at $90^{\circ} \mathrm{C}$

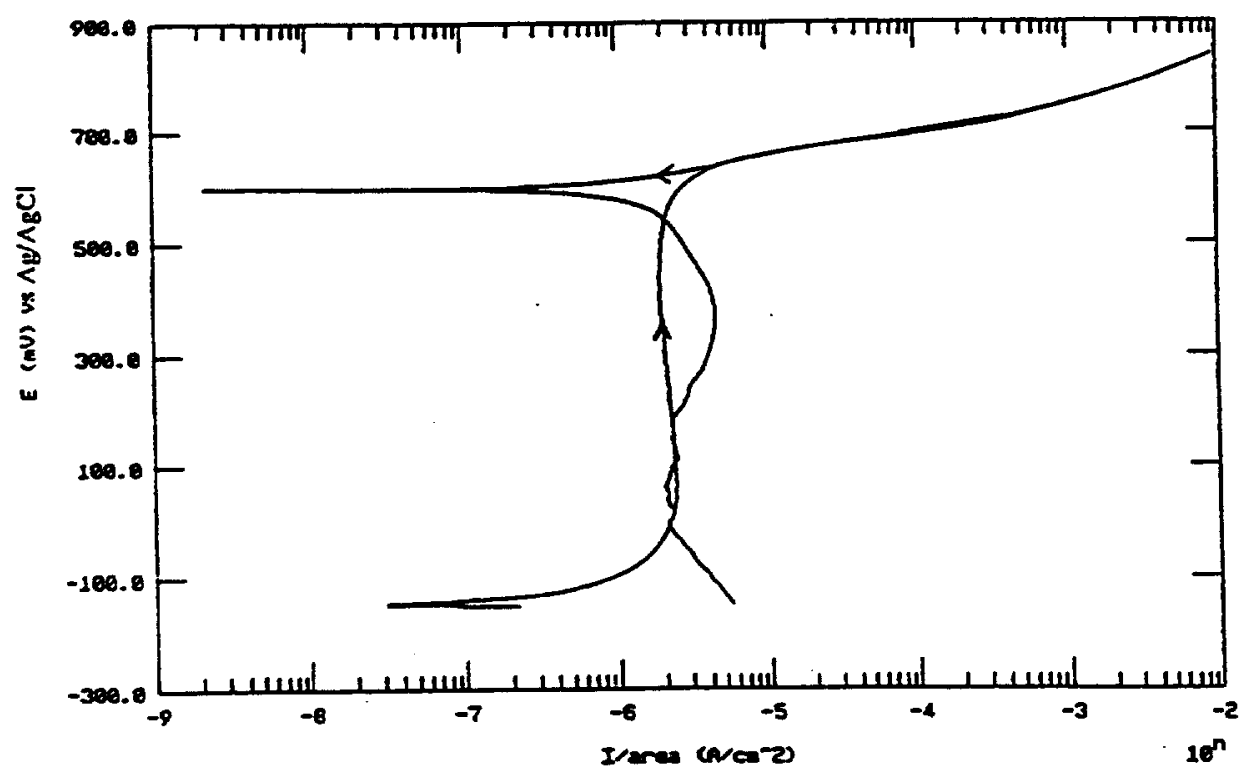

Figure 4. CPP Diagram of Alloy C-22 in Acidic Brine Containing $5 \mathrm{wt} \% \mathrm{NaCl}$ at $90^{\circ} \mathrm{C}$ 


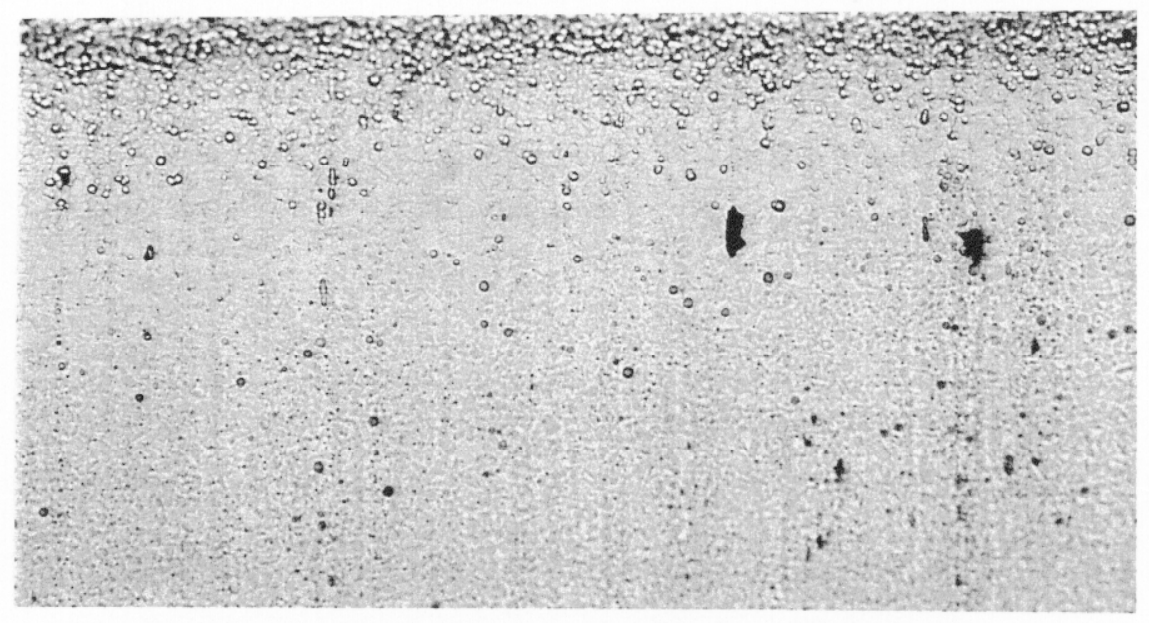

Figure 5. Microstructure of Untested Alloy 625 Specimen. 200X. Etchant: 4\% Nital Electrolytic.

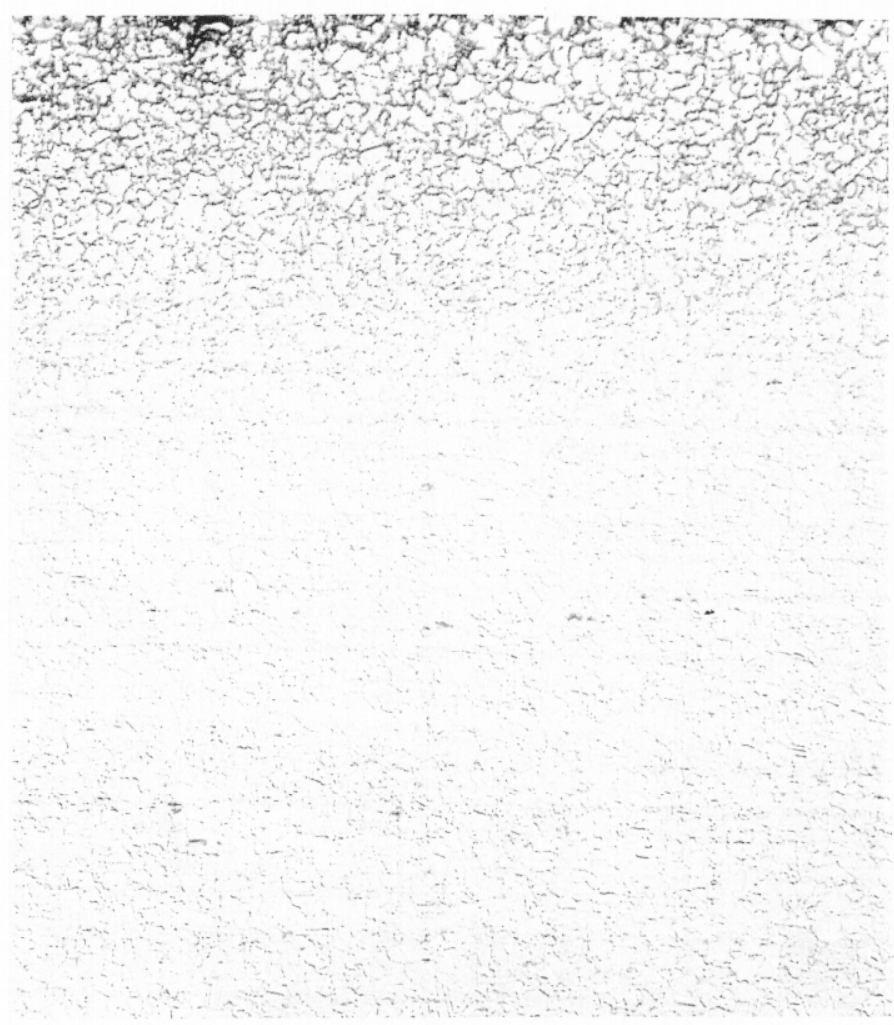

Figure 6. Microstructure of Polarized Alloy 625 Specimen. 200X. Etchant: 4\% Nital Electrolytic. 


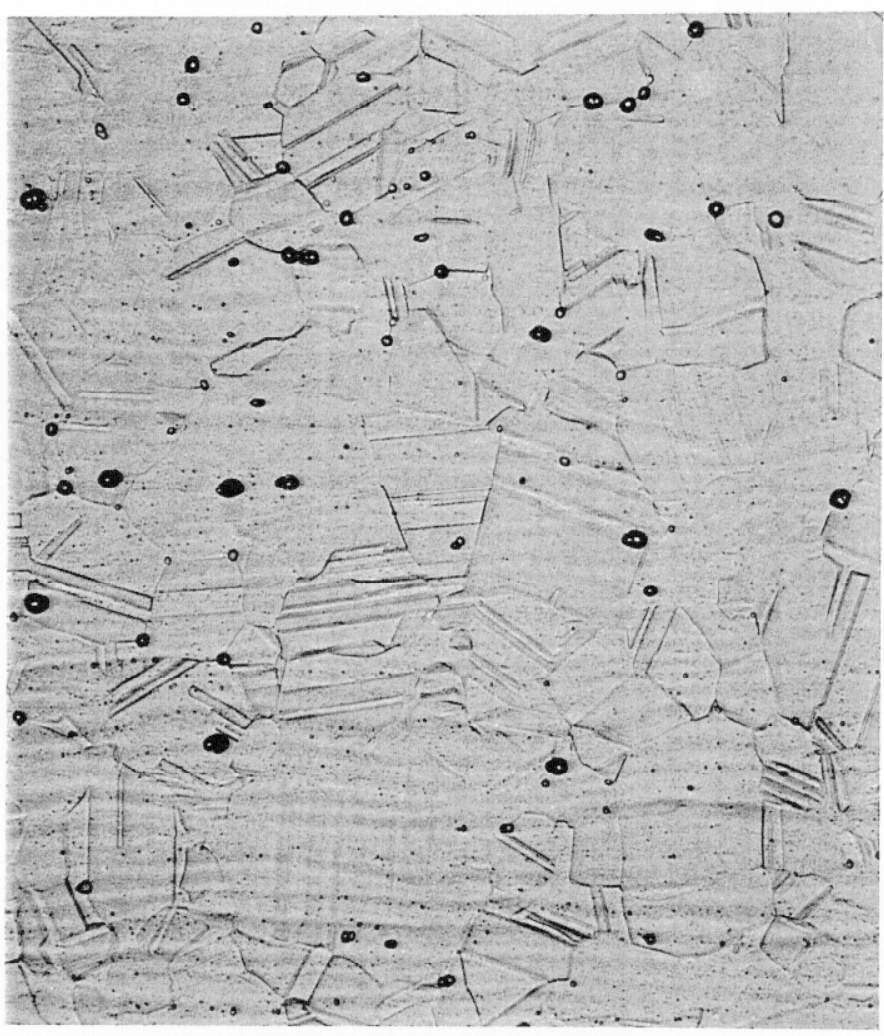

Figure 7. Microstructure of Untested Alloy C-22 Specimen. 200X. Etchant: 4\% Nital Electrolytic.

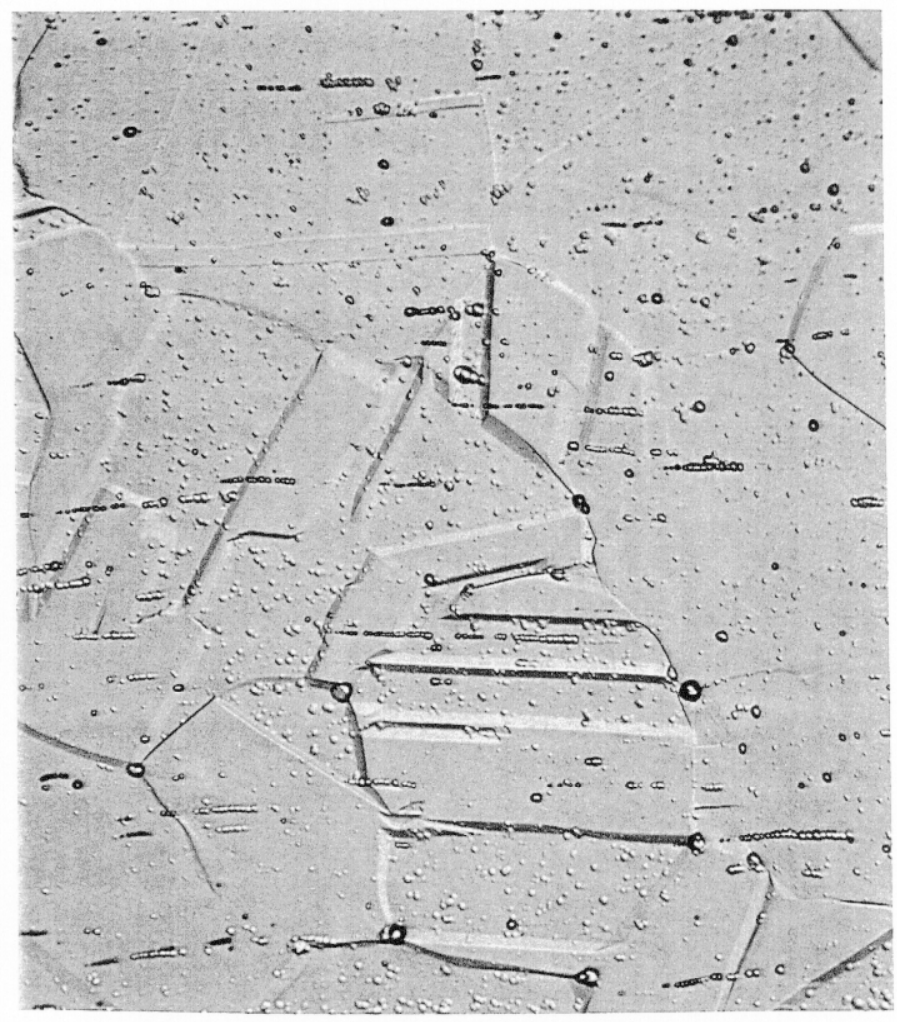

Figure 8. Microstructure of Polarized Alloy C-22 Specimen. 200X. Etchant: $4 \%$ Nital Electrolytic. 


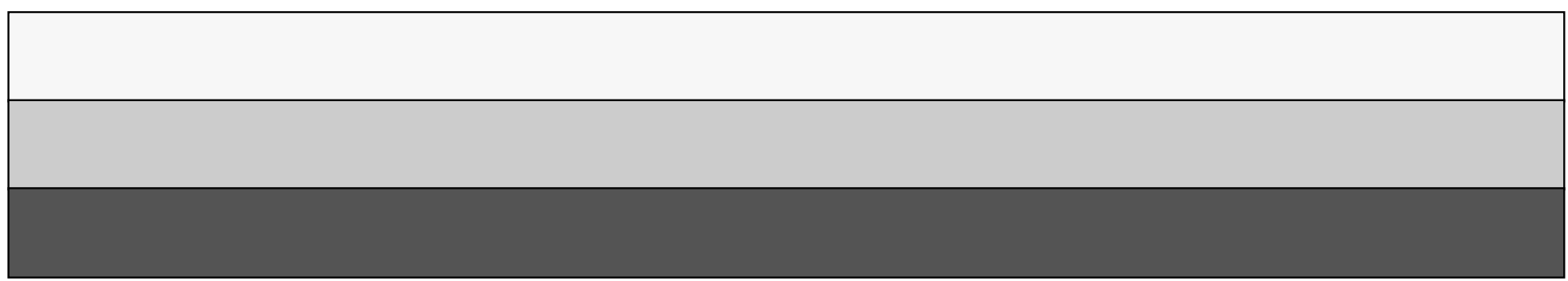

